International Journal of Engineering \& Technology, $7(3.14)(2018) 412-420$
International Journal of Engineering \& Technology
SPC
Website: $\frac{\text { www.sciencepubco.com/index.php/IJET }}{\text { Research paper }}$

\title{
Features of the Taxation in the Territories with the Special Mode of Business and Investing Activities: Comparative Analysis of the Russian and Foreign Best Practices
}

\author{
Dmitry Anatolievich Smirnov, Konstantin Aleksandrovich Strus, Anna Artemovna Avanesova \\ North-Caucasus Federal University, Pushkin Street, 1, Stavropol, 355009, Russia
}

\begin{abstract}
Preferential taxation regimes are recognized in the modern developed states as the most effective way of stimulation of entrepreneurial and investment activity. We examined the Russian mechanism of establishment of the preferential taxation regimes that have been developed for entrepreneurial and other investment activities and their infrastructure designed to provide mechanisms of operations. Our comparative analyses of the best practices in preferential taxation regimes across developing countries inform readers about advantages and risks of the investment activities and organization of business in certain territories of modern Russia. Critical appraisal of theories and practices in the formation of specific preferential taxation regimes would assist readers in the implementation of entrepreneurial and investment activity in modern Russia, revealing features of optimal regimes for specific businesses with possible mitigation or prevention of financial risks for investors. Critical comparative analysis of the best foreign practices in China, Singapore, and United Arab Emirates in the organization of foreign businesses sheds light on the most effective forms of such investment activities.

Incompleteness and fragmentariness of the Russian legislation supporting preferential taxation regimes prevent successful implementation of foreign entrepreneurial and investment activities.

The Russian legislation must be revised to ensure an attractive environment for foreign investments. Successful business and innovative activities would be possible only by the realization of the following legally significant steps: 1) adoption of the basic legislation 2) statewide programs supporting the development of free economic zones of advanced economic development.
\end{abstract}

Keywords: special regimes of entrepreneurial and investment activity in Russia; Business stimulation; Stimulation of investment activity; zones of economic development.

\section{Introduction}

Integration of the legal and economic activities in modern States, the globalization of different aspects of technology and human capital is the main characteristic of the modern civilization. Proposed development models often suggest contradicting solutions for many problems related to modernization of economic and social relations in the modern world. Emerging changes in market relations require new legislation, techniques and methods able to ensure advanced economic development.

Reduction in tax burden has been shown effective in stimulation of economic development to ensure the revitalization of international trade, to accelerate the integration of local business into the world economic system, trade and supply chains. Major forms of tax incentives are free trade, reduction of taxation for export production, the development and implementation of high technologies, the establishment of integrated industrial zones, exportoriented production of goods of mass consumption and other activities.

In modern Russia, the major legislation stimulating economic development is the establishment of special regimes of economic activities in individual territories with legal mechanisms for the implementation of entrepreneurial or investment activity different from other Russian territories. Such legal regimes are established in order to attract foreign capital, modern high-tech foreign technology, advanced production and management experience.
One of the main legal instruments supporting the establishment of special economic regimes in individual territories is the establishment of a special system of taxation for business and investment activities. The knowledge of the established Russian legislation and legal instruments in the implementation of such activities and practices would inform foreign investors about guaranteed by the state business opportunities and preferential taxation regimes on the territory of modern Russia. Critical appraisal of the Russian legislation would assist various stakeholders in successful entrepreneurial activity and in mitigation of the risks in preferential taxation.

\section{Methods}

Completeness and reliability of the presented research are supported by the diverse methodology. Given the interdisciplinary character of our study, the authors used the following methods.

Dialectical method. We used a dialectical method as a general scientific approach aimed at identifying patterns in the legal framework of taxation and economic growth in the territories with special regimes of entrepreneurial and investment activities in modern Russia.

The formal legal method. We used formally legal (dogmatic) method to examine the mechanisms of taxation with exact definitions of conceptual basis and operational categorical framework to 
allocate the logical, linguistic, terminological, and conceptual features on the subject.

Synergetic method. We used a synergistic method to determine the special place of free economic zones in self-organization of modern society, considering the regularities in the formation and functioning of free economic zones, as well as random positive (negative) factors of social reality, influencing the formation of such zones.

The historical method. We used historical methods for the analyses of consistencies in the design of the territories with a special regime of entrepreneurial and innovative activities to summarize the experience in the organization of such zones in developing countries.

The comparative legal method. We used the comparative legal method of prevailing ideas about the organization of territories with special regimes of entrepreneurial and innovative activities and free economic zones of China, the United Arab Emirates to determine their general and special properties.

Instrumental method. We used the instrumental method to demonstrate the value of preferential taxation regimes in the effective development of entrepreneurial and innovative activity in modern Russia. This method would allow the readers to identify the existing relationship between the specified target in the mechanism of legal regulation and the means of its achievement shows the possible difficulties and obstacles in the implementation of such activities.

Method of the law-making experiment. We used the law-making experiment to test legal innovations in a certain area (field) of application, implemented by the competent bodies of the state, bodies of state formations and bodies of municipal entities. We aimed at verification and the analysis of legal provisions including the preparation, implementation and conduct of the programs related to the establishment of preferential taxation regimes for investment entrepreneurial and innovative activities in modern Russia.

In addition to the methods listed above, we employed universal principles of scientific knowledge (objectivity, comprehensiveness, historicism, the unity of theory and practice), general scientific and special (particular sociological, psychological) methods, which allow extrapolation of our conclusions about the modern system of taxation in the investment business and innovation.

\section{Literature Review}

We present here the work of the Russian scientists that investigated the mechanisms of regulation of entrepreneurial and innovative activities. Popondopulo V. F. considered legal regimes of entrepreneurial activity in general but did not focus on the promotion of such activities [1]. Belitskaya A.V. studied legal regulations of investment projects on the territories with the special regime of entrepreneurial activity in modern Russia and other countries [2] However, she did not conduct a comprehensive comparative analysis of the issue. K. N. Nilov revealed the issues of the development and improvement of the special legal regimes of entrepreneurship in Kaliningrad región [3]. S. N. Shishkin introduced mechanisms of state regulation of economy in conditions of global financial economic crisis [4]. V. V. Kuschenko explored special regimes of foreign economic activity [5]

Several authors explored certain aspects of stimulating entrepreneurial activity with taxation mechanisms in other countries. Feinberg and Husted studied the mechanisms of tax incentives for relocation of businesses in certain areas of the United States [6]. Leandra Lederman analyzed issues related to judicial activities in the implementation of entrepreneurship in the USA [7]. Graetz and Warren explored the use of tax incentives for business development in the European Union [8].

Of the particular interest and relevance to our study was the scientific development by Shen W., Vanhullebusch M who examined the organization of Shanghai free trade zone and direct mecha- nisms of attracting foreign investments to promote the economic development of China [9]. The authors emphasized the creation of favorable conditions for the effective development of the financial sector, along with the marked economic and political difficulties associated with legislation changes [9]. Waters JJ examined the provision of tax privileges and rightly pointed out that the definition of the territories with tax restrictions, in fact, is the product of the agreement between investors and the state in providing significant tax and customs tariff incentives [10].

The literature review of foreign authors and Russian scientists shows a lack of critical systemic understanding of the mechanism of taxation in the territories with special regimes of entrepreneurial and investment activities in modern Russia. This lack of systemic critical understanding precludes wide implementation of preferential taxation regimes to ensure accelerated economic development in various sectors of the Russian economy.

Comparative analysis shows that despite the extensive experience in the development of special economic zones in China and the United Arab Emirates, these countries still do not have unified legislative acts regulating preferential taxation regimes. The highest state authorities make decisions related to the preferential taxation regimes in the form of local provisions specific to the respective territories. Overall coordination of activities and development of advanced economic zones are entrusted to special bodies interdepartmental commissions consisted of representatives of various ministries and departments.

\section{Results}

The legislation of the Russian Federation provides a possibility of the creation of various economic zones and territories under certain conditions for residents to apply for the preferential tax regimes in income taxes, value added taxes, severance taxes and other obligatory payments. Examples of such economic zones and territories include regional investment projects, special economic zones, zones of territorial development, free economic zones, and territories of the advanced social and economic development.

The following requirements are imposed on investors on the volume of capital investments: according to the investment declaration, investments must be at least 50 million rubles $(>\$ 86,500)$ during three years and at least 500 million rubles $(>\$ 865,000)$ during five years from the date of inclusion of the organization in the register of participants of regional investment projects. Participants of regional investment projects have the right for a preferential rate of the taxation on the income tax and value-added tax. Russian legislation established the lowered income tax rate for the organizations and residents of the special economic zone. This reduced income tax is 13,5 percent or less on condition of maintaining the separate accounting of the income (expenses) within versus outside of the special economic zone.

The special economic zone is determined by the Government of the Russian Federation part of Russian territory with advanced entrepreneurial regimes and applied custom-free enforcement areas. The special economic zones are created for nine years or less without extension. Special economic zones are created for the development of manufacturing industries, high-tech industries, port and transport infrastructure, technology development, and commercialization of their results, as well as tourism and health resort areas. There are four types of special economic zones in the territory of the Russian Federation: 1) industrial and production; 2) technology development; 3) tourist and recreational; 4) port. Preferential taxation in special economic zones results in the development of productive forces, the financial and commodity markets, acceleration of social and economic development of certain territories. Taxpayers are exempted from value-added tax when releasing the goods for domestic consumption in accordance with the customs procedure if special tax regimes are not applied and taxpayers do not engage in the sale of goods without tax payment (with the exception of applying the tax rate of 0 percent). 
Territorial Development Zones are determined by the Government of the Russian Federation parts of the Russian territory where residents are provided with a state support and custom -free measures to accelerate socio-economic development of the Russian Federation by forming the favorable conditions for attracting investments in its economy. The Territorial Development Zones are created for 12 years without extension. Residents of Territorial Development Zones are entitled to tax benefits, including investment tax credit. Detailed regulation of tax incentives is carried out in accordance with the Tax Code of the Russian Federation and includes reduced payments for investment taxes, followed by a phased payment of the loan amount and accrued interest.

Territories of advanced socio-economic development in the Russian Federation are created by the Government of the Russian Federation based on the proposals from the authorized Federal body. Territories of advanced socio-economic development are created for seventy years and may be extended by decision of the Government of the Russian Federation. Preferential taxation regimes for the residents of the Territories of advanced socioeconomic development as well as residents of free ports include zero (zero) percent of income tax.

In addition, tax rate payable to the regional budgets may not exceed 5 percent over five tax periods from the time of the first documented profit in the territory of advancing socio-economic development. The payable tax rate may not be less than 10 percent over the next five tax periods.

Free economic zones (the territory of the Republic of Crimea and the federal city of Sevastopol) assume the creation of specific regimes of implementation of entrepreneurial and other activity in custom-free enforcement area. Free economic zones are created for 25 years and provide the following opportunities for the preferential taxation for the participants:

- $\quad$ Exempt from value added in the custom- free enforcement area;

- $\quad 0$ (zero) percent of income tax paid to the federal budget and maximum 13.5percent income tax paid to the budget of the local subjects of the Russian Federation;

- $\quad$ exempt from property tax on property of the organization created or acquired for conducting activity in the territory of a free economic zone within ten years since documenting of the specified property.

\section{Discussion}

The Russian President mandated the Government of the Russian Federation in 2012 to ensure the high position of Russia in the rating system of the World Bank, «Doing Business» (http://www.doingbusiness.org/data/exploreeconomies/russia). Russian rating improved from the 120th position in 2011 to the 50th position in 2015 with a projected rise to the 20th position in 2018. In the last rating published on October 25, 2016, Russia was in 40thplace among 190 analyzed countries, which is higher by 11 positions in comparison with the last year. First place in the rating was won by New Zealand, and Singapore, the leader of last year, took the second place.

The rating of ease and comfort of doing business is measured with several indicators including protecting minority investors, simplicity of property registration, availability and simplicity in getting construction permits and getting electricity and connection to various networks, credits availability, effective taxation, trading across borders, enforcing contracts, resolving insolvency, and labor market regulation.

State' support of preferential taxation regimes in the territories with advanced socio-economic development provides a mechanism for the improving Russian rating by the World Bank. Technical and innovative special economic zones, the innovative center Skolkovo are among the most known examples of such government support.
International examples of the state support of economic development include research parks focused on technology-oriented businesses in the USA, scientific parks in the United Kingdom, industrial parks in the People's Republic of China on in CIS countries (Tajikistan, Moldova, Belarus, Uzbekistan). Despite different names, such territories share identical legal regimes and a major goal - support of innovative business activities.

Comparative analysis of international practices in the developing countries demonstrates that creation of investment parks is closely related to the implementation of tax incentives. Preferential taxation regimes are implemented as a result of the agreement between investors and the states aimed at the attraction of financial resources for significant social and economic activities of certain territories. For instance, Chinese government actively supported free economic zones to promote the social and economic development of the separate territories. According to the preferential economic and taxation regimes in free economic zones, local administrative Steering Committees have provincial government' rights in the regulation of local economy and development of the corresponding regulatory framework. In particular, they are independent in matters of borrowing funds in the world and domestic credit markets or in the external distribution of bond within the limits provided by the central government. At the same time, they accept liability for all risks they undertake.

The present limit of foreign investments into the objects in free economic zones in China constitutes of $\$ 50$ million US dollars (earlier \$ 30,000,000 US dollars.). Investments of a foreign resident must constitute at least 25 percent of the authorized nominal capital in the created entity. Enterprises in free economic zones have preferential rates of income tax and 5-year «tax holidays» with a complete or partial exemption of income tax (no income tax during the first 2 years and 50percent of an effective rate during the next 3 years). Until 2008, the preferential rate of income tax was 15 percent in economic free zones in comparison with 33 percent in other Chinese territories outside of preferential zones.

Decree of the State Council of the People's Republic of China «Regulations of the People's Republic of China on the Implementation of the Enterprise Income Tax Law» adopted in December 26, 2007, established 5-year transition period in income taxes for entities of free economic zones as following: 18 percent in 2008, 20 percent in 2009, 22 percent in 2010, 24 percentin2011, and 25 percent since 2012 to the present time. This law applied only to residents registered before March 15, 2007, who used preferential rate of income tax of 15 percent. «New» residents registered after March 15, 2007, have to pay 25 percent income tax since January 1,2008 . For residents with a preferential rate of the income tax of 24 percent (e.g., residents of zones of cross-border cooperation, the «open» seaside cities) the rate of the specified income tax was increased to 25 percent since 2008.

Residents of free economic zone engaged in trade, manufacturing and reprocessing, repair and also in import and export transactions have to pay 15 percent in value-added taxes as residents of all other territories of the People's Republic of China. However, residents of free economic zones exempt from value added tax and customs payments for importing production equipment and materials on account of their share in the entity. The tax on economic activity, consumer tax (excise tax), the individual income tax and other types of taxes existing in the People's Republic of China are paid by the residents of the free economic zone at the same rates as in other territories of the country.

Local administrations can provide export-oriented or high-tech enterprises with non-tax privileges, for example, in the form of reducing or full relief from payments for use of land, water, electricity, gas, the Internet, lease of buildings, etc.

Residents of free economic zones can lease land for housing construction for 70 years; for industrial use, construction of facilities of science, health care, education, culture, or sport for 50 years; for objects of trade, tourism or entertainment for 40 years; and for complex use for 50 years. Leasehold is granted after payments of 
the market value of the land without payments of land tax. Lease contract can be extended on an annual basis for an additional fee. Residents of free economic zones have rights to purchase the real estate. The real estate tax constitutes 1.2percent of the real estate value, in case of a lease to 12 percent of lease cost. Residents of free economic zones including the foreign enterprises can act in Chinese market independently or through intermediary stateowned companies. When establishing the prices of the products, residents are obliged to consider recommendations of the local departments controlling the prices. Prices for products must comply with prices of similar goods in other Chinese enterprises.

Main administrative economic objects with preferential taxation regimes in modern China include:

- 5 special economic zones (Shenzhen, Zhuhai, Shantou, Xiamen, Hainan, and Pudun);

- $\quad 90$ zones of technical and economic development of the national level in Beijing, Shanghai, Guangzhou, Tianjin, Dalian, Harbin, and other large cities;

- $\quad 114$ zones of new and high technologies, including the famous science and technology park of «Zhongguancun» in Beijing, parks of high technologies in Shanghai, Tianjin, and Nanjing and open zones of high technologies in Chengdu and Guangzhou;

- 13 free customs zones in Shanghai, Tianjin, Dalian, Guangzhou, Ningbo, Zhangjiagang, Haikou, Xiamen, Fuzhou, Qingdao, Shantou, Zhuhai, and Shenzhen;

- 14 zones of cross-border economic cooperation of the national level in Heihe, Suifenhe Manzhouli, Erlianand others;

- the zone of free economic trade in Shanghai that was officially opened on September 29, 2013, according to the decision of the State Council of China.

The main types of free economic zones include a zone of technical and economic development, zones of new and high technologies, free customs zones, the zone of cross-border economic cooperation and zones of free economic trade. The Shanghai free trade area covers a bonded zone of Waigaoqiao, the logistic park of Waigaoqiao, the port zone Yangshan and a complex bonded zone of the airport Pudun.

By estimates of the Chinese experts, Shanghai free trade area differs from the special economic zones and customs areas existing in the People's Republic of China. For instance, the Shanghai free trade zone has a wider range of objectives than bonded zones, traditional for China. The bonded zones existing since 1990 in China are generally directed to attract the foreign equity by the provision of tax benefits during the work in a zone, simplifications of currency and customs control and simplification of investing activities. Main objective of Shanghai free trade zone is not the only attraction of the foreign investment, but also approbation of new methods of state regulation of international trade, foreign investments, and financial sector. Secondly, free trade zones differ from zones of technical and economic development, traditional for all Chinese large cities. Unlike traditional zones focused on industrial production, free trade zones focus on international trade and customer service.

Thirdly, free trade zones differ from the traditional model of free ports (for example, Hong Kong or Singapore) which attract businesses by freedom of trade, lack of currency exchange control, freedom of navigation, high openness to the foreign equity and a low tax burden. Shanghai free trade zone uses the experience of free ports, but its major goal is the accumulation of existing experiments in the development of Chinese economy in general. Economic development through reforms and increased transparency and openness for further implementation of economic innovations in all country remains the main objective of this zone.

Foreign researchers noted a contradiction between the establishment of the preferential customs duties and requirements to the established article 3.1(a) of the World Trade Organization's Agreement on Subsidies and Countervailing Measures (SCM Agreement) because incentives in export processing zones can be qualified as prohibited export subsidies. Resolution of the contradiction is feasible by the development and adoption of single standards of corporate social responsibility (CSR) by foreign investors realizing the activities in the territory of investment parks [10].

Available research clearly demonstrated that creation of free economic zones in China provided the following benefits for the organization of business activity. First, a wide range of services for foreign investment became available. In free economic zones, foreign investors are provided with new opportunities in banking activity, insurance, financial credits, and conditions for the establishment of credit assessment centers (credit history bureaus), recruitment agencies and investment companies.

1. Banking activity: international financial organizations conforming with qualifying standards have an opportunity to create banks with 100percent of foreign capital as well as credit institutes joint with the Chinese financial organizations. Chinese banks created in the territory of free trade zones and Cross-Border Economic Cooperation Zones have an opportunity to engage in offshore financial services.

2. Medical insurance: companies with foreign capital can provide services in voluntary medical insurance (healthcare insurance) in free trade zones.

3. Leasing: Restrictions to the minimum size of the authorized nominal capital are cancelled when leasing companies in free trade zones create subsidiary companies under separate projects (leasing of the ocean ship or the equipment). Besides, leasing companies in free trade zones have an opportunity to be engaged at the same time in commercial factoring.

4. Sea transport: there are fewer requirements placed on mutual and joint cooperative enterprises involved with international shipping (separate rules have been established by the Ministry of transport of the People's Republic of China).

5. Telecommunication services: Enterprises with foreign capital can provide some types of telecommunication services (with the consent of the State Council of China if modification of the corresponding administrative legal acts is required).

6. Gaming machines and devices: Enterprises with foreign capital can be involved in production and marketing of the gaming equipment. Gaming equipment can be sold in China after the Ministry of Culture of the People's Republic of China verified and approved gaming content.

7. Credit history bureaus: Enterprises with foreign capital can assess the creditworthiness of Chinese organizations and individuals in free trade zones.

8. Tourist activities: Creation of joint share travel agencies is authorized in free trade zones. Such travel agencies can sell foreign tours to the Chinese clients.

9. Recruitment agencies: Creation of joint mutual enterprises of Chinese and foreign capital engaged in recruitment of human resources is authorized in free trade zones. Foreign share in such entities cannot exceed 70percent. The minimum size of the authorized nominal capital for recruitment agencies with the foreign capital was reduced from $\$ 300,000$ to $\$ 125,000$ in Shanghai free trade zone. Besides, service providers from special administrative regions in Hong Kong and Macau have an opportunity of creation of 100percent of affiliated recruitment agencies.

10. Investment companies: in the free trade zones, a creation of joint-stock investment companies with foreign capital is authorized.

11. Construction and design: Enterprises with foreign capital can provide design services in Shanghai trade free zone. Unlike implementation of other joint projects, there are no restrictions in the maximum participation of foreign investors. Construction companies with 100percent of foreign capital can be created in Shanghai free trade zone.

12. Agents on the organization of performances: A creation of the enterprises with 100percent of foreign capital engaged in the organization of commercial performances with the participation of foreign actors is allowed in Shanghai free trade zone. 
13. Entertainment industry: A creation of the enterprises with 100percent of foreign capital engaged in entertainment and show business is allowed in Shanghai free trade zone.

14. Educational services: Joint commercial educational institutions and commercial professional training institutions in the form of the joint cooperation businesses can be created in free trade zones.

15. Medical services: Wholly foreign-owned medical institutions and enterprises with 100percent of foreign capital can be created in free trade zones.

Secondly, a registration of the companies with foreign capital is simplified. The notification procedure for the registration and establishment of enterprises with foreign capital is adopted on October 1, 2013, in free trade zones. In contrast, newly created Chinese companies face a long procedure of approval and registration by local authorities of the People's Republic of China. It is enough to notify the Committee for the Management of Free Trade Zone about a creation of the company in Shanghai. A notification of registration can be submitted as an application on the website of the Management of the Free Trade Zone. The application is submitted after a reservation of the name of the created company in Shanghai Municipal Administration of Industry and Commerce. Together with the notification of registration, the founder of the entity is obliged to give assurance that the foreign investor and the company with the foreign capital would not violate the law of the People's Republic of China and would not harm sovereignty of the People's Republic of China, public interests, state security, and the environment. After filing of an application within 30 days from the date of the notification, it is necessary to be registered in Shanghai Municipal Administration of Industry and Commerce.

The simplified registration order doesn't apply to the entities included in "Negative List" of special restrictions for foreign investments in Shanghai free trade zone. Besides, the simplified registration order does not cancel preliminary verification of the security of mergers and acquisitions, declaration of economic concentration or other requirements stipulated by Chinese antitrust laws.

Comparative analyses allocate more than 20 free-trade economic zones in the United Arab Emirates. Distinctive features of business regulations in free-trade economic zones include 100percent foreign ownership of the authorized nominal capital of the company (there is no need of cofounders with UAE citizenship); exemption of income taxes (as a rule, within 50 years); complete repatriation of the capital and income and absence of customs payments. Each zone has been created for maintaining a certain type of activity, for example, for trade in jewellery (Gold and Diamond Park) or for maintaining high-technology types of business (Dubai Internet City). At the same time, almost all free economic zones allow registration of the companies engaged in import/export or engaged in providing consulting services excluding companies engaged in tourism, public transportation and so forth.

Company registration in free-trade economic zones in the United Arab Emirates is possible after the contribution of the standard authorized nominal capital, which is returned upon registration completion. The second step in company registration is licensing. There are four license types for the companies in free-trade economic zones: industrial license, limited trade license, license for consulting services and open trade license. Office availability (rent) and entrance visas for each cofounder are needed for registration completion of newly created companies in the free-trade zone in the United Arab Emirates.

The most known free economic zones of the UAE include Dubai Technology and Media Free Zone (Dubai Internet City, Dubai Media City and Knowledge Village) (www.dubaiinternetcity.com). Dubai Airport Free Zone Authority (DAFZA) (http://www.dafz.ae/index.html) and Jebel Ali Free Zone are located in the Emirate of Dubai (http://www.jafza.ae). The other Emirates support free-trade zones as well. Ajman Free Zone is located in the emirate Adzhman (http://www.afza.gov.ae/en/).
Ahmed Bin Rashid Free Zone is located in the emirate of Ummahs Al Kuveyn (http://www.emiratesfreezone.com). Fujairah Free Zone is located in the emirate Fudzheyra (www.fujairahfreezone.com). Hamriyah Free Zone is located in the emirate of Sharjah (http://www.hfza.ae/home.php). Ras Al Khaimah Free Trade Zone is located in the emirate of Races of $\mathrm{Al}$ Haym (http://www.rakftz.com/) and Sharjah Airport International Free Zone is located in the emirate of Sharjah (www.saifzone.com).

Comparative analysis of free-trade economic zones in modern Russia shows that they have been created according to the special law. There were 33 free-trade economic zones $(9$ industrial and production types, 6 technology development types, 3 port zones and 15 tourist and recreational types) in 30 subjects of the Russian Federation on January 1, 2016. According to the Russian Ministry of Economics, more than 400 investors from 29 countries actively invested in Russian free-trade economic zones in 2006 -2016. During this period, free-trade economic zones paid to the Russian federal budget more than 40 billion rubles of taxes and customs payments $(\sim 684,990,400)$. From 21 billion rubles of tax payments, productive activity contributed 59percent, and technology development contributed40.6percent. Preferential taxation and customs privileges in trade-free economic zones during this time summed around 22.6 billion rubles [11].

The legislation of the Russian Federation provides preferential taxation regimes for the residents in free -trade zones including privileges in payments of corporate income taxes, value added taxes, mineral extraction taxes and other mandatory payments. Preferential taxation regimes in the Russian Federation are implemented in regional investment projects, special economic zones, zones of territorial development, free economic zones, and the territories of the advanced social and economic development.

Regional investment projects include only projects intended for the production of goods in compliance with the requirements of the article 25.8 of Tax Code of the Russian Federation [12]. At the same time, regional investment projects cannot be engaged in oil production and (or) refinery, natural gas production and (or) gas condensate, oil or gas transportation; production of excisable goods (excluding cars and motorcycles), or in the implementation of activities without corporate profit tax. Regional investment projects can be implemented at the same time in several subjects of the Russian Federation.

In addition to the restrictions above, regional investment projects cannot be implemented in the territories with other types of preferential tax regimes including an economic zone of any type or the territory of the advanced social and economic development. Investors in regional investment projects cannot be members of consolidated elected taxpayer' groups and cannot participate in the implementation of more than one regional investment project.

There are two sets of requirements for participants of regional investment projects related to the number of capital investments. In particular, it concerns the size and the duration of investments: according to the investment declaration, investments must be at least 50 million rubles $(>\$ 86,500)$ during three years and at least 500 million rubles $(>\$ 865,000)$ during five years from the date of inclusion of the organization in the register of participants of regional investment projects. The second group of requirements is similar by the number of capital investments. In this case, the Tax Code of the Russian Federation specifies a time period preceding a day of the beginning of the implementation of capital investments within the implementation of the regional investment project, but not earlier than January 1, 2013.

Participants of regional investment projects have preferential rates of income tax and the value-added tax (See article 1.5 and 1.5-1 chapter 284, article 2-5 chapter 284.3, article 2 chapter 284.3-1, article .2 chapter $342.3-1$ Tax Code of the Russian Federation). Residents of the special economic zones have lower income tax paid to the local budgets ( $\leq$ than 13,5 percent) from the activities performed in the territory of special economic zones under separate accounting of income (expenses) gained (suffered) inside 
versus outside the territory of the special economic zone (Art. 284 of the Tax Code of the Russian Federation) [12].

Special economic zones are created for the development of manufacturing industries, high-tech industries, manufacturing of new products, port and transport infrastructure, technology development, and commercialization of their results, as well as tourism and health resort areas.

The types of special economic zones created in Russia include industrial and production zones, technology development zones, tourist and recreational zones, and free ports.

It should be noted that special economic zones can be created on the state-owned land and (or) municipal property as well as on the land owned by citizens or legal entities. Special economic zones can be created on land owned by the state or municipal property, including those granted for possession and (or) use of citizens or legal entities, as well as on land owned by individuals or legal entities. These plots of land should belong to the category of land for industry, energy, transport, communications, broadcasting, television, computer, land for space activities, land defence, security or other special purposes or land settlements. Touristrecreational special economic zones can also be created on land belonging to the category of lands of specially protected territories and objects, or forest land, agricultural land. Allowed include the boundaries of special economic zones the land on which there are buildings, which are in state or municipal property, including those granted for possession and (or) use of citizens or legal entities, as well as the land on which located buildings, owned by individuals or legal entities [13].

Russian government makes decisions on the creation of special economic zones upon the requests from the federal and local executive organs and administrative municipal bodies. The supreme executive organ of state power of subjects of the Russian Federation or the highest executive body of state power of subjects of the Russian Federation together with the executive and administrative body of the municipality or executive and administrative bodies of municipalities served in the Government of the Russian Federation authorized federal executive body for the application for the establishment of a special economic zone substantiating the appropriateness and effectiveness of its creation to solving the problems of the federal, regional and local importance. An application for the creation of port special economic zone on the basis of objects of the seaport infrastructure, river port, airport attached a written consent of the owner or owners of infrastructures in the territory, intended for creation of special economic port zone. The consent of the owner or owners of the infrastructure may not be withdrawn before the conclusion of an agreement on the implementation of activities in the port special economic zone. The procedure for registration and submission of applications for the creation of special economic zones, including the list of documents attached to the application, determined by the authorized Government of the Russian Federation, federal executive body [13].

Legal agreements are signed within 30 days from the request and include:

1) the perspective plan of development and financing of special economic zones;

2) liability of executive bodies of the Russian Federation in transfer to the federal executive authority the rights for the management and disposal of the land and other real estate objects located in a special economic zone for the period of its existence;

3 ) liability of executive bodies of the municipalities in transfer to the federal executive authority the rights for the management and disposal of the land and other real estate objects located in a special economic zone for the period of its existence;

4) organization of the Supervisory Board of the special economic zone;

5)performance indicators of the special economic zone;

6)other conditions.

The special economic zone is created for no more than forty-nine years without extension. Federal laws may have exceptions to the rules. For example, the free port "Vladivostok" was created for 70 years [14]. Early termination of the special economic zone is allowed only if:

1) there is a need of protection of life and human health, conservation and cultural values, ensuring the defense of the country and safety of the state;

2) there were no any agreements on the implementation (management) of industrial-production, technical-promotional, touristrecreational activities within three years from the creation of the special economic zone and/or all previous agreements have been terminated;

3) within three years from the creation of the special economic zone, there were no business activities, industrial production, technology development, tourist and recreational activities or activities for a construction, reconstruction and operation of infrastructure facilities of the seaport, river port, or airport.

The Government of the Russian Federation makes decisions on early termination of special economic zones.

Preferential taxation regimes have been implemented in more than in 30 special economic zones created on the basis of the Federal law of July 22, 2005 No. 116 «About special economic zones» [13]. Other special economic zones have been created based on other federal laws in Kaliningrad and Magadan regions. Preferential taxation regimes stimulate the development of productive forces, financial and commodity markets, the acceleration of socio-economic development in Kaliningrad and Magadan regions [15]. Preferential taxation regimes are applicable only to the taxpayers registered in the administrative territory of Kaliningrad and Magadan regions and under specific conditions. The special economic zone in the Magadan Region is defined by the administrative borders of the city of Magadan, and in the Kaliningrad region by the whole territory of this region. For instance, preferential taxation regimes are applicable only to full subjects of the special economic zones. Enterprise entities can receive legal participant' status in the special economic zone after 1) registration and 2) inclusion in the unified register of residents of the special economic zone. If registered participants violated the legislation of the Russian Federation and economic activities set by the federal law, the administration of the special economic zone has the right to cancel the registration judicially by excluding from the unified register or by cancelling the registration certificate. After that, taxpayers have no right to enjoy preferential taxation regimes. The preferential taxation regimes in Magadan region include low rates of income taxes and the value-added taxes until December 31 , 2025.

The preferential taxation regimes require separate accounting of the transactions of financial and economic activities performed within the special economic zone in Magadan region and in the entire Magadan region. Russian legislation on taxes and fees regulate the preferential taxation regimes in Magadan region. For instance, municipal Magadan law stipulates that organizations participants of the special economic zone in Magadan region pay lower income tax rate to the regional budget from business activities performed in the entire region. Regional income tax cannot be higher than 13,5 percent and the federal income tax rate is 0 percent (Chapter 284 Russian Tax Code. Part 2). In case of coal production, residents of the special economic zone of Magadan region have lowered coefficient deflator in the calculation of severance tax. Taxpayers - participants of the special economic zone in the Magadan region, engaged in the extraction of minerals, except hydrocarbons and common minerals on subsoil areas located wholly or partly in the Magadan region, pay tax on minerals mined in the relevant section of the subsoil, 0.6 ratio (Federal law of 23.11.2015 N 321-FL) [16].

Preferential taxation regimes in the special economic zone of Kaliningrad region are regulated by articles $151,171,173,288.1$ and 385.1 of the Tax Code of the Russian Federation and the regional Kaliningrad legislation [12]. Preferential taxation regimes include low-income tax, added value and property taxes. Taxpayers in the special economic zone in Kaliningrad do not pay value-added tax 
for the goods produced for domestic consumption if other preferential taxation regimes are not applied and the taxpayer is not engaged in marketing of the goods without tax payment (except for the application of the tax rate of 0 percent). Residents use specific preferential income tax regimes for the profit received from the implementation of investment projects on condition of separate accounting of the income (expenses) received (made) from such projects versus other economic activities.

The Federal law «About the special economic zone in Kaliningrad region» adopted on October 1, 2006, regulates preferential income tax regimes from investment projects. Income tax calculations are based on income or expenses in the form of the positive (negative) exchange differences arising from the re-evaluation of property currency value in light of the exchange rate of foreign currency to the currency of the Russian Federation. Reassessed currency values (except for the securities nominated in foreign currency) include bank accounts, liability value (except for the issued (received) in advance payments), and also positive (negative) exchange difference arising from a deviation of selling rate or purchase of foreign currency from the official rate established by the Central bank of the Russian Federation. The income tax from implementation the investment projects is 0 percent during six tax periods (The tax period for the profit tax of organizations is one year) from the date of inclusion of the legal entity (organization) in the unified register in the special economic zone in Kaliningrad region.

During the next six tax periods, the income tax from the implementation of the investment project is 50percent less when compared with income tax estimated according to the Tax Code of the Russian Federation for all other Russian taxpayers (Article 284.1 of the Tax Code) [12]. Property tax is 0 percent within six calendar years from the date of inclusion of the legal entity (organization) in the unified register of residents of the special economic zone in Kaliningrad region (Article 385.1 in The Tax Code of the Russian Federation) [12]. During the following seventh to twelfth calendar years, property tax of the organizations engaged in investment projects is 50percent less when compared with property tax estimated according to the Tax Code of the Russian Federation for all other Russian taxpayers.

Territorial Development Zone is a part of the Russian Federation where residents are provided with measures of the state support for the purpose of acceleration of social and economic development of the subjects of the Russian Federation by forming favorable conditions for foreign investments. The zone of territorial development is created for 12 years [17]. Residents of Territorial Development Zones have the right for tax benefits, including to provision of the investment tax credit [17]. The detailed regulation of tax incentives in Territorial Development Zones is performed according to the legislation on taxes and fees of the Russian Federation. For example, according to sub-article 6 of article 1 in Chapter 67 of the Tax Code of the Russian Federation, a registration in Territorial Development Zones is the basis for preferential investment tax credit [12]. Preferential investment tax regimes include a longer period of tax payment up to 10 years expressed in a decrease in payments for a certain tax followed by a phased payment of the loan amount and accrued interest.

Territories of advanced socio-economic development in the Russian Federation are parts of Russian territory, including the closed administrative-territorial entities, on which the Government of the Russian Federation implements particular legal regimes stimulating business and other entrepreneurial activities. Territories of advanced socio-economic development are created to attract foreign investment ensuring the accelerated social and economic development and creation of comfortable conditions for the population wellbeing.

Territories of advanced socio-economic development are created for seventy years according to the decision of the Government of the Russian Federation. The free port of Vladivostok consists of municipal territories of Primorye Region : Artemovskiy urban district of Vladivostok city district, urban district of Bolshoy Ka- men, Nakhodka city district, guerrilla urban district, city district Spassk-Far, Ussuriysk city district, the Nadezhda municipal district Shkotovsky municipal district, Oktyabrsky municipal district Olginsky municipal area, guerrilla municipal district, municipality of the Borderceiling elements area of the municipal district of Khasan, Khanka municipal area, including onshore and offshore ports, located on the territory of these municipalities [14]. This time interval can be extended according to the decision of the Russian Government.

Preferential taxation regimes in Territories of advanced socioeconomic development as well as in the free port of Vladivostok include federal income tax of 0 (zero) percent. In addition, regional income tax cannot exceed 5 percent during five tax periods since the first profit from the activities implemented in Territories of advanced socio-economic development and free port of Vladivostok [12].

Free-trade economic zones include the Republic of Crimea and the federal city of Sevastopol with specific entrepreneurial and preferential tax regimes and custom-free trade activities. The free economic zones are created for 25 years. A person intending to obtain the status of free economic zone participants must be registered in the Republic of Crimea and the territory of the federal city of Sevastopol was held at the tax records with the tax authority, as well as to have an investment return that corresponds to the requirements of this federal law.

The person referred to in paragraph 1 of this article, is the supreme executive body of the Republic of Crimea or the highest executive organ of the state power federal city of Sevastopol a statement in writing of the contract on conditions of activity in the free economic zone (hereinafter - the applicant) with the following documents:

1) copies of the constituent documents (for legal entities);

2) A copy of state registration of the legal entity or individual entrepreneur;

3) a copy of the certificate of tax registration (Chapter 13 "Member of the Free Economic Zone "of the Federal Law" On the development of the Crimean Federal District and the free economic zone on the territory of the Republic of Crimea and the federal city of Sevastopol" N 379-FL) [18].

In particular, participants do not need to pay value-added tax (subarticle 3 of article 1.1, Chapter151 of the Tax Code of the Russian Federation). Participants of free-trade economic zones do not pay the federal income tax, and in regional income tax cannot exceed 13.5 percent (Article 1.7, Chapter284 of the Tax Code of the Russian Federation) [12].

In addition, participants of free-trade economic zones are exempted from the property tax on the property created or purchased for conducting business activities in free-trade economic zones within ten years since registration of the specified property. The Tax Code of the Russian Federation provides preferential taxation regimes for land value taxes for a period of three years since the established land ownership in free-trade economic zones.

According to Kremlin' assessment, territories of the advanced economic development show positive results in contrast with inefficient free-trade zones. The report by the Control Department of the Russian President demonstrated that since 2006, 186 billion rubles $(\$ 3,181,870,380)$ were spent for the development of 33 special economic zones, 24 billion rubles of them were not used, while the amount of tax and customs payments from special economic zones constituted only $40,000,000,000$ rub $(\$ 684,273,200)$. The cost of the creation of one work in a special economic was $10,000,000 \mathrm{rub}$ - that in general constitutes an average salary in Russia of one person for 25 years (Special zones at special prices 2016).

Critical analysis of experience in the organization of the special economic zones identified several barriers to their effective development. First, there is a common societal belief that developed in Russia liberal market regime makes the development of special economic zones impractical. Obtaining preferential taxation regimes is directly related to the possibility created by the country's 
top leadership. Development of the centers of free entrepreneurship including free -trade economic zones, is justified only in state-planned economy with the centralized form of the government. In state-planned economies, preferential taxation regimes serve as a peculiar «window» in the tax-market environment Such «windows» create favorable conditions for the breakthrough of the national economy beyond some advanced boundaries. That is why preferential taxation regimes for entrepreneurial and innovative activity remain the main tool in implementing a reasonable policy of sustainable economic development.

Second, the successful development of entrepreneurship and innovative activities requires preliminary investments in infrastructure in addition to the preferential taxation regimes.

Budget constraints in Russian Federation preclude adequate investments in infrastructure. The Ministry of Finance and Federal Tax Service have exhausting struggle for each penny in budget revenue. Therefore, the government does not always support the projects without immediate dividends and, moreover, does not allocate significant resources to such projects.

For example, the most conservative estimates suggest that a "promotion" of a free economic zone Nakhodka in Primorsky Krai, which has enormous export potential, requires at least 15-20 million dollars of state investments. Only after such investments, multiplicative income effect can be expected. However, the state has not invested even 10percent of the required capital. Similar situations are identified in Kaliningrad and Magadan regions. Direct state investments were very modest in Ingushetia as well. The government provision of investment loans with an interest rate at the level of inflation may offer a feasible solution to this problem.

Third, development of an entrepreneurship and innovations in a certain territory cannot be provided by a simple territorial determination. A simple territorial determination does not result in spontaneous economic development. A clear understanding of who would be engaged in administration and management and what outcomes are expected from entrepreneurial and business activities is essential for a successful implementation of advanced economic zones.

In other words, the development of entrepreneurship and innovations should be initiated by businesses rather than legally imposed At the present moment, the creation of special economic zones is followed by huge constructions of useless infrastructure without clear understanding who and how will use it.

Forth, preferential taxation regimes proposed to attract or retain business operations do not work effectively in Russia. The established tax benefits are too small to motivate sharp business investments or production decisions in some specific places. Preferential taxation regimes do attract or retain significant entrepreneurial investments now and in the near future.

In contrast with Russian experience, preferential taxation regimes in other developing countries are much more mature with less common «black» schemes of tax evasión [19, 20, 21]. It is necessary to recognize that Russian engagement in international initiatives including implementation of the Common Reporting Standards by the Organization for Economic Co-operation and Development works toward the elimination of tax evasion in the Russian Federation $[21,22]$. Such initiatives aim at elimination of offshore tax evasion and require transparent exchange of financial information about account holders from all global financial institutions regardless of taxpayer residency [21].

Fifth, establishment of rather small tax benefits does not attract «startup» businesses without considerable current assets. Existing preferential taxation regimes in Russia do not allow rapid growth of venture capital for the subsequent development of «startup» businesses.

\section{Conclusions}

Based on our research we concluded that that forming of the effective environment for entrepreneurship and innovative business activities require a long-term strategy for territorial development and implementation of the following legal steps: 1) adoption of the basic legislation and 2) development of the program of creation and development of free economic zones. Such work shall be performed by the relevant ministries and departments in response to proposals from regional administrations and local government bodies. Executive responsible government bodies must specify detailed sources of financing and costs of infrastructure facilities, administrative buildings and manufacturing constructions. In this regard, we conclude that the development program should include the following sections:

- main directions in the policy of creation and development of free-trade economic zone;

- the analysis of the functioning of the free-trade economic zone on territories of the country and measures to increase their efficiency;

- the registry of the existing and planned free economic zones with justification for their creation and development;

- the material, financial, labor and other resources necessary for the implementation of the federal program, including resource allocation from the federal budget.

There are no doubts that executive rather than legislative bodies of the government should have the authority to create, regulate and liquidate free economic zones. Responsible ministries in coordination with regional authorities should provide the federal program of the development coordination and control of business activities in free economic zones as well as proposals of international treaties of the Russian Federation in this sphere.

Regardless of types of entrepreneurial activities, administrative bodies should be created for zones of export production, manufacturing free-customs zones, and free-trade zones. All free economic zones are obliged to report to the Government of the Russian Federation as well as to executive regional bodies and local territorial governments.

Main functions of administrations in free economic zones include: - development program organization and implementation, designing and construction of factories, warehousing, transport buildings and control of their operation;

- the issue of permissions (licenses);

- assistance in contracts related to lease (sublease) of state-owned or municipal property including land, manufacturing buildings and transportation;

- control of the implementation of investments and business activities by participants of free economic zones;

- representation of interests of participants of free economic zones in the federal and regional government bodies;

- assistance in the creation of commercial banks, development funds and insurance companies.

Administrations of the free-trade zone have similar functions with an additional authority to provide the contractual basis of services for storage, sorting, processing, and marketing of goods and commercial services. The Government of the Russian Federation in coordination with local executive bodies appoints and eliminates Heads of free economic zones. A single administration of several free economic zones located within one region can be formed in some cases. Supervisory boards consisted of business and government representatives coordinate and control all activities in free economic zones. 


\section{References}

[1] V.F. Popondopulo, Pravovoj rezhim predprinimatel'stva [Legal regime of entrepreneurship], St. Petersburg State University Publishing House, St. Petersburg, 1994.

[2] A.V. Belitskaya, Pravovoe regulirovanie realizacii investicionnyh proektov na territorijah so special'nym rezhimom osushhestvlenija predprinimatel'skoj dejatel'nosti [Legal regulation of the implementation of investment projects in the territories with a special regime for the implementation of entrepreneurial activities], Biznes, menedzhment i pravo 2 (2012) 34-38

[3] K.N. Nilov, Voprosy sovershenstvovanija special'nogo pravovogo rezhima predprinimatel'stva $\mathrm{v}$ Kaliningradskoj oblasti [Issues of improving the special legal regime of entrepreneurship in the Kaliningrad region], Vestnik Rossijskogo gosudarstvennogo universi$\begin{array}{llllll}\text { teta im. } & \text { I. } & \text { Kanta } & 9 & \text { (2012) }\end{array}$ https://journals.kantiana.ru/vestnik/2807/7727/. Accessed July 2, 2018.

[4] S.N. Shishkin, Gosudarstvennoe regulirovanie ekonomiki nekotorye uroki globalnogo finansovo-ekonomicheskogo krizisa [State regulation of the economy: some lessons of the global financial and economic crisis], Biznes. Menedzhment. Pravo 1 (2009) 34

[5] V.V. Kuschenko, Osobye rezhimy vneshnejekonomicheskoj dejatel'nosti: pravo i praktika [Special regimes of foreign economic activity: law and practice], Knizhnyi mir, Mooscow, 2014.

[6] R.M. Feinberg, T.A. Husted, Patterns of establishment entry and state-level antitrust, Journal of Competition Law and Economics 7(4) (2011) 813-823. doi:10.1093/joclec/nhr013.

[7] L. Lederman, W(h)ither economic substance?, Iowa Law Review 95(2) (2010) 389-444

[8] M.J. Graetz, A.C. Warren Jr, Income tax discrimination and the political and economic integration of Europe, Yale Law Journal 115(6) (2006) 1186-1255.

[9] S. Wei, M. Vanhullebusch, Where is the Alchemy? The Experimen of the Shanghai Free Trade Zone in Freeing the Foreign Investment Regime in China, European Business Organization Law Review 16(2) (2015). https://ssrn.com/abstract=2611085. Accessed July 2 , 2018 .

[10] J.J. Waters, Achieving World Trade Organization Compliance for Export Processing Zones While Maintaining Economic Competitiveness for Developing Countries, Duke Law Journal 63 (2013) 481-524.

[11] S.D. Okun, Osobye zony po special'nym zakonam [Special zones at special prices]. Kommersant. https://www.kommersant.ru/doc/3008286. Revised June 9, 2016. Accessed July 2, 2018.

[12] Tax Code of the Russian Federation. Consultant http://www.consultant.ru/document/cons_doc_LAW_19671/. Accessed July 2, 2018.

[13] Federal Law of the Russian Federation from 22.07.2005 N 116-FZ (edition from 18.07.2017) "On special economic zones in the Russian Federation". http://www.consultant.ru/document/cons doc LAW 54599/. Accessed July 2, 2018.

[14] Federal Law of the Russian Federation from 13.07.2015 N 212-FL (the latest edition) "On the free port of Vladivostok". Consultant. http://www.consultant.ru/document/cons doc LAW 182596/. Accessed July 2, 2018.

[15] Federal Law of the Russian Federation from 31.05.1999 N 104-FL (the latest edition) "On Special Economic Zone in the Magadan region". Consultant. http://www.consultant.ru/document/cons_doc_LAW_23257/. Accessed July 2, 2018.

[16] Federal law from 23.11.2015 N 321-FL. Consultant http://www.consultant.ru/document/cons_doc_LAW_28165/b0945 496f341b2d7e1f79e0bc9dd4e4522a466b1/. Accessed July 2, 2018.

[17] Federal Law of the Russian Federation from 03.12.2011 N 392-FZ (the latest edition) "On Territorial Development Zones in the Russian Federation and on Amending Certain Legislative Acts of the Russian Federation". Consultant. http://www.consultant.ru/document/cons_doc_LAW_122563/. Accessed July 2, 2018.

[18] Federal Law of the Russian Federation from 29.11.2014 N 379-FL (latest revision) "On the development of the Crimean Federal District and the free economic zone on the territory of the Republic of Crimea and the federal city of Sevastopol”; № 48. Chapter 6658; № 15. Chapter 2053.
[19] S. Braguinsky, S. Mityakov, A. Liscovich, Direct estimation of hidden earnings: Evidence from Russian administrative data, The Journal of Law and Economics 57(2) (2014) 281-319.

[20] C. Fuest, N. Riedel, Tax evasion, tax avoidance and tax expenditures in developing countries: A review of the literature, Report prepared for the UK Department for International Development (DFID), 2009.

[21] A. Yakovlev, 'Black Cash' Tax Evasion in Russia: Its Forms, Incentives and Consequences at Firm Level, Europe-Asia Studies 53(1) (2001) 33-55.

[22] Automatic Exchange of Information: What It Is, How It Works, Benefits, What Remains To Be Done. Organisation for Economic Co-operation and Development. http://www.oecd.org/tax/exchangeof-tax-information/automaticexchangeofinformationreport.htm. Revised July 23, 2012. Accessed July 2, 2018.

[23] D.Z. Kerzner. D.W. Chodikoff, Automatic Exchange of Information International Tax Evasion in the Global Information Age, Springer, 2016, pp. 283-312. 